\title{
19: 16599754-16547838
}

National Cancer Institute

\section{Source}

National Cancer Institute. 19: 16599754-16547838. NCI Thesaurus. Code C41998.

Physical location of CRSP7_Gene 